PRINT ISSN 1119-8362

Electronic ISSN 1119-8362
Full-text Available Online at

https://www.ajol.info/index.php/jasem

http://ww.bioline.org.br/ja
J. Appl. Sci. Environ. Manage.

Vol. 25 (5) 799-804 May 2021

\title{
Effect of Cloud Cover on Land Use Land Cover dynamics using Remotely Sensed Data of Western Niger Delta, Nigeria
}

\section{${ }^{* 1}$ UCHEGBULAM, O; ${ }^{2}$ AMELOKO, AA; ${ }^{3}$ OMO-IRABOR, OO}

\author{
${ }^{* 1}$ Department of Physics with Electronics, Western Delta University, Oghara, Nigeria \\ ${ }^{2}$ Department of Petroleum Engineering, Covenant University, Ota, Nigeria \\ ${ }^{3}$ Department of Earth Sciences, Federal University of Petroleum Resources, Effurun, Nigeria \\ *Corresponding Author Email: okezie_uchegbulam@yahoo.com; Other Authors Email: tonyameloko@yahoo.co; \\ omoirabor.omoleomo@fupre.edu.ng
}

\begin{abstract}
The effect of cloud cover on land use land cover (LULC) changes in the tropical region of Western Niger Delta was investigated. Landsat images of more than 11/2 decades (2002-2019) of path 189 row 056 with bands 1-5 were used for the analysis. Supervised classification was applied to obtain the LULC statistics. Cloud cover for 2002, 2014 and 2019 were $0.48 \%, 0 \%$ and 32\% respectively. The extracted statistics shows that cultivation, built-up area, exposed soil, secondary regrowth and water body increased between 2002 and 2014 . These LULC except oil spills decreased between 2014 and 2019. These LULC were expected to record further increment between 2014 and 2019 due to increase in population. Dense forest and light forest maintained a decrease over the entire period. The real values were affected by cloud appearing as noise in 2019 image, which is a problem in a damp and humid climate. Climate change could be another reason because the data were acquired in the dry season. The satellite image of 2019 may not be used for accurate land mapping due to the high value of cloud cover. This has shown the effect of dynamic nature of climate in the region and the importance of supervised classification in the analysis of satellite images.
\end{abstract}

DOI:https://dx.doi.org/10.4314/jasem.v25i5.17

Copyright: Copyright $(92021$ Uchegbulam et al. This is an open access article distributed under the Creative Commons Attribution License (CCL), which permits unrestricted use, distribution, and reproduction in any medium, provided the original work is properly cited.

Dates: Received: 20 March 2021; Revised: 27 April 2021; Accepted: 07 May 2021

Keywords: cloud cover, land cover, landsat imagery, satellite image

Land cover monitoring is so significant that neglecting land use mitigation, which is made possible through documentation of land covers in an area, will lead to serious negative impact on the environment. There is the need for timely, accurate and documentation of land covers because of its dynamics and global impact (Hanson and Loveland 2012). A cloud consists of droplets of liquid water and it forms when air is heated by the sun. It covers the sky mainly in the wet seasons of tropical regions of the world, it is measured in okta. Clouds are significant in the earth's climate system because of their effects on radiation from the sun, radiation from the land, and rainfall. These effects depend on cloud altitude, thickness, horizontal extent, horizontal variability, water content, liquid or ice phase and the sizes of droplets and crystals. There is the need to distinguish different types of clouds. The appearance of clouds is always taken to show characteristic atmospheric dynamical processes. So the conventional classification by Meteorologists of cloud types based on their appearance continues to be used in classification of cloud study processes. Degree of cloud describes the extent of cover by clouds in the portion of the sky visible from the observation point.
It is estimated by the weather observer and given in eighths by the synoptic service. The following classification is usually made. Clear $-0-1 / 10$ th covered; Scattered - 1/10th-5/10th covered; Broken 5/10th-9/10th covered; Overcast - fully covered (Rokonuzzaman and Rahman, 2017). Generally, clouds formation happens in either of these ways: Foremost, clouds may form when the air mass is cooled below its dew point. This may occur when the air ascends or comes into contact with a cold surface. This can take place in situation when cold and warm air masses collide, and the less dense warmer air is lifted to higher altitude. It can also occur where air masses are moving across a mountain range, or it may be caused by convection current due to warming of the ground surface below. Secondly, Clouds may form when warm air blows over a low temperature surface such as a water surface. Lastly, Clouds can be formed where the air temperature increases gradually or remains stable, but the air mass quickly takes in water vapor from a surface under till it reaches the dew point. This often happens where cold and dry air masses flow across a warm ocean surface without ice cover (Rokonuzzaman and Rahman, 2017). Western Niger 
Delta is a major oil and gas producing area in southern Nigeria. Therefore, requires regular monitoring of its land covers to know the dynamics. Landsat images, being the satellite data of choice has offered Researchers the opportunity to assess and monitor land cover dynamics in different parts of the world (Yang and Lo, 2002; Bakr et al 2010). Land covers like dense and light forests in different parts of the world have been studied extensively using Landsat imagery. Twumasi and Merem (2006) utilized Geographic Information System (GIS) and remotely sensed data in the evaluation of change in a coastal environment in the Niger Delta Region of Nigeria. They reported increase in environmental issues such as habitat degradation, gas flaring, coastal wetland loss, water pollution, destruction of dense and light vegetation and other environmental concerns.

Uchegbulam and Ayolabi (2013) used Landsat imagery to study land cover changes in Western Niger Delta. They reported depletion of wetland and dense forest and an upsurge in builtup area. Varieties of spatial and temporal mappings has been successfully carried out using remote sensing (Foody, 2002). Wali et al., (2019) investigated oil spill incidents and wetland loss in Niger Delta. They reported continuous incidences of oil spillage and loss of wetland in the area. Cloud cover is a major problem in satellite data acquisition in the humid climate of tropical regions $(\mathrm{Ju}$ and Roy, 2008) which Western Niger Delta region is not an exception. The effect of high humidity in the Niger Delta region is abundance of cloud cover. Mean annual rainfall in the region ranges $2540-4046 \mathrm{~mm}$ (Ishaku and Majid, 2010).Mapping land covers such as various vegetations covers in tropical and subtropical regions using optical sensors, more problems arises due to the frequent high cloud coverage, which further lowers the number of available and needed observations (Asner, 2001).

The effect of cloud cover on land cover classification has not been adequately investigated in the study area, hence the need to conduct such a study. The objectives of the study are to show the effect of cloud cover in the 2019 satellite image of the region, to compare it with land cover statistics of previous years and to make recommendations.

\section{MATERIALS AND METHOD}

Description of the Study Area: Nigeria lies between latitude $4^{0} \mathrm{~N}$ to $14^{0} \mathrm{~N}$; and along longitude $3^{\circ} \mathrm{E}$ to $15^{\circ} \mathrm{E}$. It is bounded in the North by Niger Republic, in the West by Benin Republic and in the East by Republic of Cameroon. To the North-East is Republic of Chad and Atlantic Ocean is to its South through the Gulf of Guinea. The study area is the Western part of Niger
Delta (Figure 2). The area lie between latitude: $5^{0} 32^{\prime}$ $\mathrm{N}$ and $7^{0} 09^{\prime} \mathrm{N}$ and longitude: $5^{\circ} 09^{\prime} \mathrm{E}$ and $6^{\circ} 20^{\prime} \mathrm{E}$ and it covers about $180 \mathrm{~km} \mathrm{x} 180 \mathrm{~km}$ which is approximately $32,000 \mathrm{~km}^{2}$. A delta is an area where the rate of sediment supply is higher than rates of subsidence and is proximal to a body of standing water. The deposition of some of its sediment load from the rivers exceeds its rate of removal. River Niger is the main drainage system from which other distinct river systems originate. The region has a humid equatorial climate. The cloud cover is quite high, with relative humidity and average rainfall above $80 \%$ and $3000 \mathrm{~mm}$ respectively. The study area consists of wetlands, coastal sands, mangrove swamps, and Sombreiro-Warri plains (Omo - Irabor and Oduyemi, 2006). Water table is close to surface; about 4 to $5 \mathrm{~m}$ beneath the surface. Directions of water flow are towards the tributaries which drain into the Atlantic Ocean. Figure 1 is map of Nigeria showing Niger Delta States, while Figure 2 shows Western and Eastern Niger Delta regions' oil fields and pipelines.

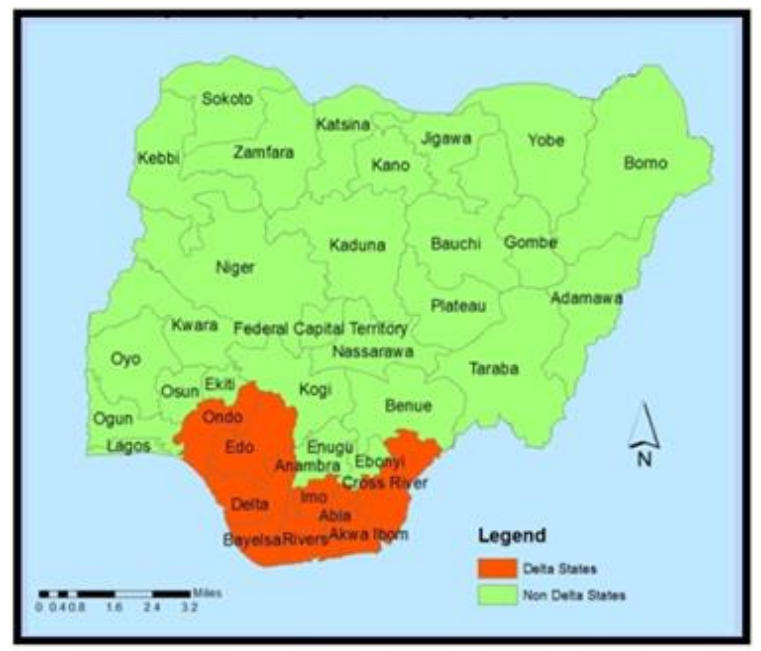

Fig 1: Map of Nigeria showing Niger Delta States (GAMERS, 2017)

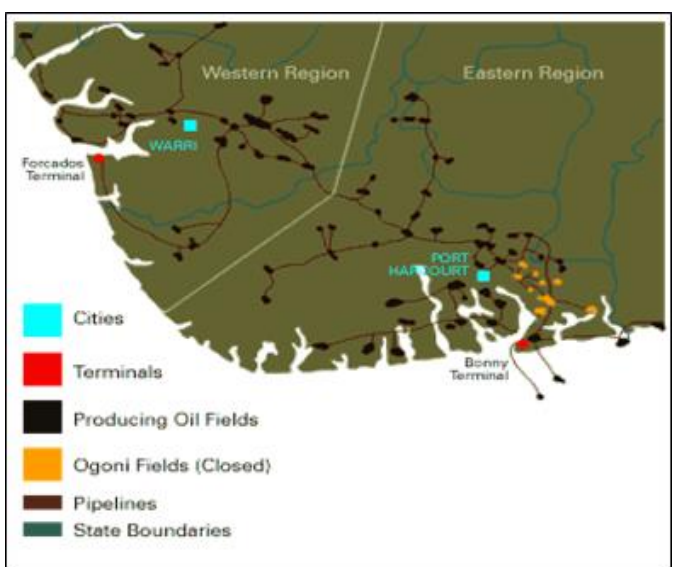

Fig 2: Map of Niger Delta showing the Western Region, oil fields and pipelines (Urhobo Historical Society, 2020). 
Data sets and Image Pre-Processing: Satellite images of 2002, 2014 and 2019 of one scene from the Worldwide Reference System (WRS-2) of path 189 and row 056 (Table 1) were obtained from the Global Land Cover Facility (GLCF) of (2002, 2014 and 2019). The wavelengths used for the analysis were bands 1-5. ILWIS 3.1 software was used for image processing and GIS analysis. Geographic coordinate system (Longitude/Latitude) of the data were converted to metric coordinate system through the ILWIS 3.1 software application.

Table 1: Landsat Image Characteristics

\begin{tabular}{|c|c|c|c|c|c|c|c|c|}
\hline $\mathbf{S} / \mathbf{N}$ & Source & Date & $\begin{array}{l}\text { Satellite } \\
\text { Data Type }\end{array}$ & Sensor & $\begin{array}{l}\text { Path/ } \\
\text { Row }\end{array}$ & Resolution & Band & $\begin{array}{l}\text { Cloud } \\
\text { Cover }\end{array}$ \\
\hline 1 & GLCF & $29 / 01 / 2002$ & LandSat -7 & $\begin{array}{l}\text { Enhanced } \\
\text { Thematic } \\
\text { Mapper Plus } \\
(\text { ETM+) }\end{array}$ & $189 / 056$ & $28.5 \mathrm{~m}$ & $1-5$ & $0.48 \%$ \\
\hline 2 & GLCF & $27 / 01 / 2014$ & LandSat -7 & $\begin{array}{l}\text { Enhanced } \\
\text { Thematic } \\
\text { Mapper Plus } \\
(\text { ETM+) }\end{array}$ & $189 / 056$ & $28 \mathrm{~m}$ & $1-5$ & 0 \\
\hline 3 & GLCF & $15 / 12 / 2019$ & LandSat -7 & $\begin{array}{l}\text { Enhanced } \\
\text { Thematic } \\
\text { Mapper Plus } \\
(\text { ETM+) }\end{array}$ & $189 / 056$ & $28 \mathrm{~m}$ & $1-5$ & $32 \%$ \\
\hline
\end{tabular}

Bands: Sensor wavelengths (bands) acquired were bands 1,2 and 3 which are visible bands with wavelength range $(0.4 \mu \mathrm{m}-0.7 \mu \mathrm{m})$. Bands 4 and 5 are near infrared bands $(0.7 \mu \mathrm{m}-1.1 \mu \mathrm{m})$. Filtering of the images were done band by band, one band at a time using the ILWIS algorithm AVG 3x3based on matrix operation.

Classifications: Nine (9) land cover classes comprising, bare-land/cultivation, built-up area, dense forest, exposed soil, light forest and oil spills were extracted from the images. Others include secondary regrowth, water body and cloud cover. Supervised Maximum Likelihood Classification Algorithm was adopted because the area is a familiar terrain. Moreover, ground truth was done to compare the extracted covers with what is on ground. The study area was the training ground during the classification process. Colour composite of B543 (bands 5, 4 and 3) were established during the filtering, to give the vegetation the required green colour.

\section{RESULTS AND DISCUSSION}

The results are presented as maps, tables and histograms. Figures 3, 4 and 5 show the processed satellite images of 2002, 2014 and 2019 respectively. While tables 2, 3 and 4 show the extracted land cover statistics from the images of 2002, 2014 and 2019 respectively. The histograms of the images 2002, 2014 and 2019 are displayed in Figures 6, 7 and 8 respectively.

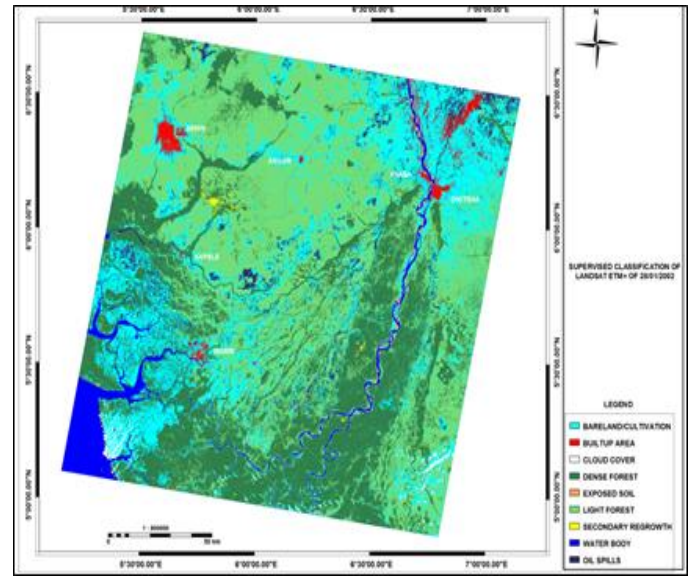

Fig 3: 2002 Land cover satellite image

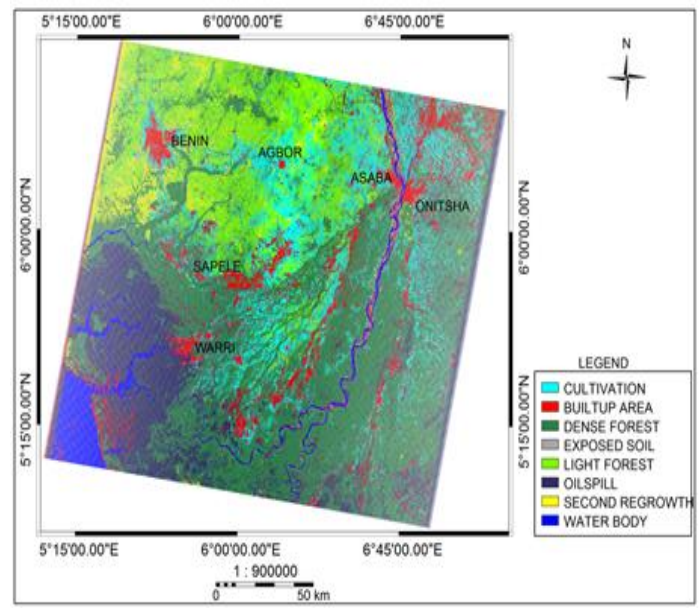

Fig 4: 2014 Land cover satellite image. 


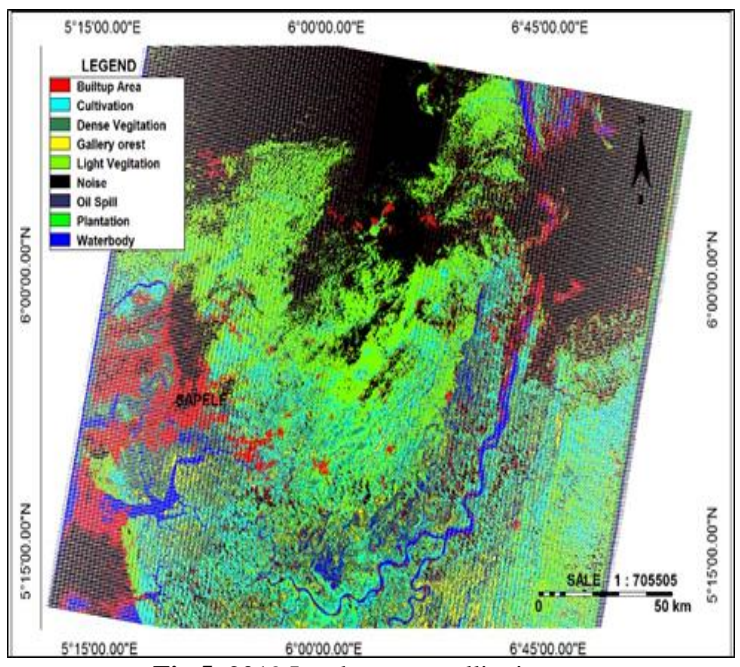

Fig 5: 2019 Land cover satellite image.

Table 2: 2002 Global Land Use Cover Statistics

\begin{tabular}{llll}
\hline Land Cover & $\begin{array}{l}\text { Area } \\
\left(\mathbf{M}^{2}\right)\end{array}$ & $\begin{array}{l}\text { Area Hectare } \\
(\mathbf{H a})\end{array}$ & $\begin{array}{l}\text { Percentage } \\
(\boldsymbol{\%})\end{array}$ \\
\hline Bareland/Cultivation & 2695620600 & 269562.06 & 7.96 \\
Built-up Area & 1476163700 & 147616.37 & 4.36 \\
Dense Forest & 11715608100 & 1171560.81 & 34.59 \\
Exposed Soil & 403005100 & 40300.51 & 1.19 \\
Light Forest & 14138889400 & 1413888.94 & 41.74 \\
Oil Spills & 2077752100 & 207775.21 & 6.13 \\
Secondary Regrowth & 64461000 & 6446.10 & 0.19 \\
Water Body & 1143166300 & 114316.63 & 3.37 \\
Cloud Cover & 161791300 & 16179.13 & 0.48 \\
\hline
\end{tabular}

Table 3: 2014 Global Land Use Cover Statistics

\begin{tabular}{llll}
\hline Land Cover & $\begin{array}{l}\text { Area } \\
\left(\mathbf{M}^{2}\right)\end{array}$ & $\begin{array}{l}\text { Area } \\
\text { Hectare }(\mathrm{Ha})\end{array}$ & $\begin{array}{l}\text { Percentage } \\
(\%)\end{array}$ \\
\hline Bareland/Cultivation & 5552331300 & 555233.13 & 17.79 \\
Built Up Area & 2589212700 & 258921.27 & 8.29 \\
Dense Forest & 6687981000 & 668798.10 & 21.42 \\
Exposed Soil & 1541864700 & 154186.47 & 4.94 \\
Light Forest & 9349983900 & 934998.39 & 29.95 \\
Oil spill & 2004023700 & 200402.37 & 6.42 \\
Second. Regrowth & 1285753500 & 128575.35 & 4.22 \\
Water Body & 2205482900 & 220548.29 & 7.06 \\
Cloud Cover & - & - & - \\
\hline
\end{tabular}

Fig 4: Global Land cover statistics of 2019

\begin{tabular}{llll}
\hline Land Cover & $\begin{array}{l}\text { Area } \\
\left(\mathbf{M}^{\mathbf{1}}\right)\end{array}$ & $\begin{array}{l}\text { Area Hectare } \\
(\mathrm{Ha})\end{array}$ & $\begin{array}{l}\text { Percentage } \\
(\%)\end{array}$ \\
\hline Bareland/Cultivation & 3659316300 & 365931.4 & 12.1 \\
Built Up Area & 2449527300 & 244952.4 & 7.7 \\
Dense Forest & 2317666500 & 231766.7 & 7.7 \\
Exposed Soil & - & - & - \\
Light Forest & 5879139300 & 587913.7 & 3.3 \\
$\begin{array}{l}\text { Oil spill } \\
\text { Secondary Regrowth }\end{array}$ & 3272073300 & 327207.1 & 11.0 \\
$\begin{array}{l}\text { (Galley Forest) } \\
\text { Water Body }\end{array}$ & 1519585200 & 151958.4 & 5.5 \\
Cloud Cover (Noise) & 9559265400 & 955926.4 & 31.9 \\
\hline
\end{tabular}

Bareland/cultivation increased from $269,562.06 \mathrm{Ha}$ in 2002 to $555233.13 \mathrm{Ha}$ in 2014 (Table 2) but decreased to $365931.4 \mathrm{Ha}$ in 2019 (Table 3).

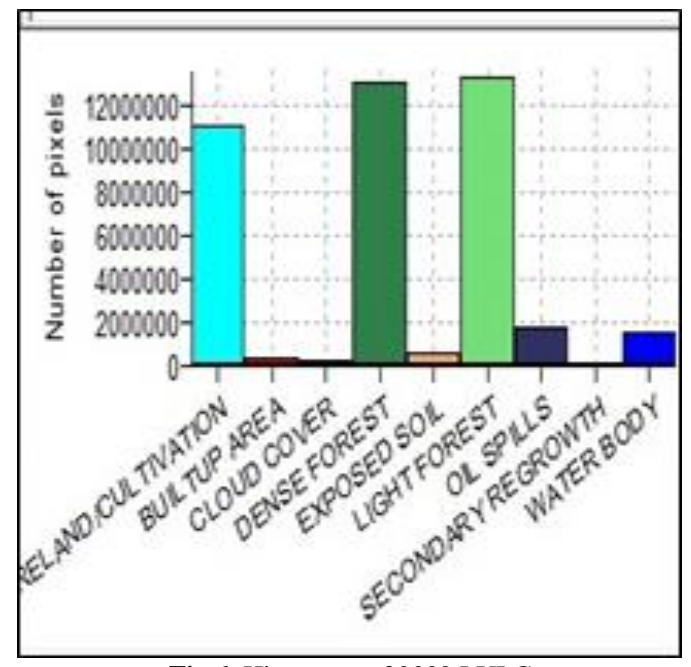

Fig 6: Histogram of 2002 LULC

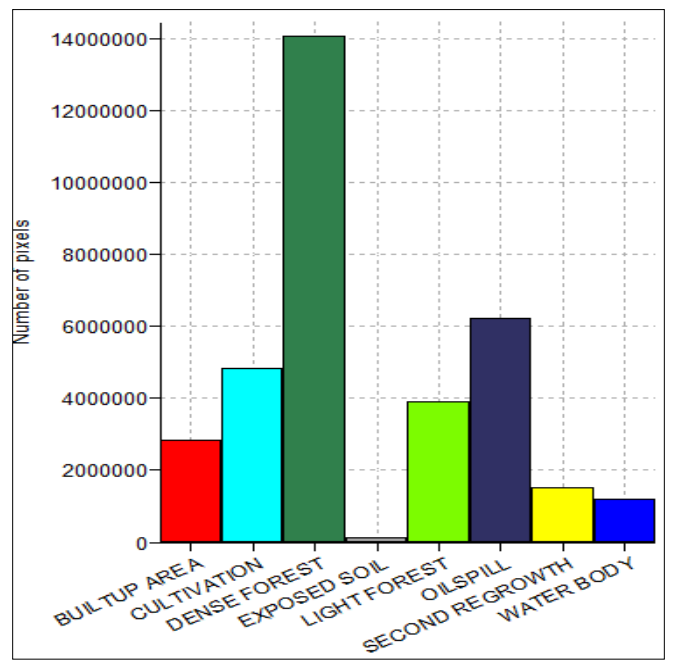

Fig 7: Histogram of 2014 LULC

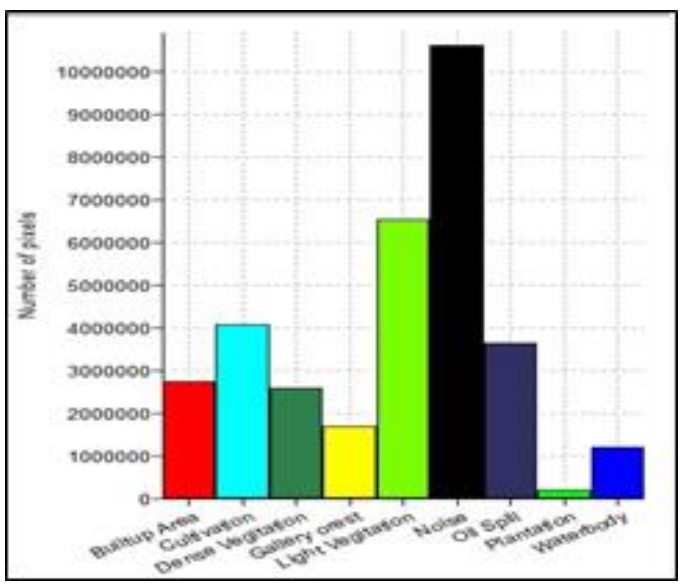

Fig 8: Histogram of 2019 LULC

The decrease in 2019 can be attributed to the obstruction of the whole cultivated land and bareland by cloud. There have been campaigns by various Governments on the need to increase food production 
due to increasing population. It has been yielding results in the study area as many people have gone into farming. Built-up area which comprises buildings and other physical structures decreased from $258,921.27 \mathrm{Ha}$ in 2014 (Table 3) to $244,952.4 \mathrm{Ha}$ in 2019 (Table 4). These may not be the true value due to the presence of high cloud cover. Builtup area is expected to maintain continued increment over the years. Wali et al, (2019) reported increment in builtup area (1984-2013) in Port Harcourt, a city in the Eastern Niger Delta. The Western region should follow the same trend because of increasing population, migration, increase in socioeconomic activities and hosts of other reasons. Dense forest maintained decrement from 2002 through to 2019 in spite of the cloud cover. This is understandable because of the percentage of depletion throughout the period. It can be attributed to the continuous logging activities for economic development-constructions of buildings, furniture and other uses of timber. Though there has been campaign on tree planting, the rate of wetland forest loss is alarming, since the rate of depletion is more than the replacement. Uchegbulam et al (2017) reported depletion of dense forest in the Western Niger delta region. Exposed soil increased from $40300.5 \mathrm{Ha}$ in 2002 to $154186.47 \mathrm{Ha}$ in 2014 , but is not captured or did not appear in 2019 statistics. Exposed soil may have been captured as builtup area in the land cover. The obstruction may have been caused by cloud cover. Light forest decreased throughout the period under consideration. The decrement can be attributed to the same reasons for the depletion of dense forest. Oil spills decreased from in $207775.21 \mathrm{Ha}$ in 2002 to $200402.37 \mathrm{Ha}$ in 2014 and increased to $327207.1 \mathrm{Ha}$ in 2019 . Though the cloud cover is high, but the increment is understandable due the upsurge of illegal makeshift refineries in the creeks of Niger Delta which leads to spillage of oil in the region. Wali et al, (2019) reported cases of oil spillage in the region. Secondary regrowth which include mangrove forest increased from $6446.10 \mathrm{Ha}$ in 2002 to $128575.35 \mathrm{Ha}$ in 2014 and decreased to $151958.4 \mathrm{Ha}$ in 2019. The true value may not have been captured due to the cloud cover.

Water bodies increased between 2002 and 2014, but decreased in 2019. There have been incidents of flooding in the region. So the depletion of water bodies may not be the true picture in the region due to the cloud cover. Cloud cover appearing as noise in the land cover statistics had a cover of $16179.13 \mathrm{Ha}$ in 2002. It did not appear in 2014, but has coverage of 955926.4 in 2019. Though the satellite data were acquired in the dry season (December 15, 2019), there have been records of heavy rains in the December period in recent years. The Niger Delta region records the highest rain $(\geq 3000 \mathrm{~mm})$ in Southern Nigeria (Ishaku and Majid, 2010).Climate change may have been the reason considering the high resolution of the satellite in acquisition of the data. Cloud cover has always been a problem in the acquisition of satellite imagery in the tropics (Asner, 2001). Being that supervised classification was employed, it could be said that the land cover statistics of 2019 may not be the true picture at this time due the high value of noise in the satellite image.

Conclusion: The satellite image analysis of the region has further shown that cloud cover is a problem in the tropics. The research work has demonstrated the importance of supervised classification as the training ground is known to the Researchers as indicated by ground truths. Environmental Watchers and Government agencies are to put into considerations the dynamics of land use land cover for optimal environmental planning in the region.

\section{REFERENCES}

Asner, GP (2001). Cloud cover in Landsat observations of the Brazilian Amazon. Int'l J. of Remote Sen. 22, 3855-3862

Bakr, N; Weindorf, DC; Bahnassy, MH; Marei, SM; El-Badawi, MM (2010). Monitoring land cover changes in a newly reclaimed area of Egypt using multi-temporal Landsat data. Appl. Geo. 30, 592605

Foody, GM (2002). Status of land cover classification accuracy assessment. Remote Sen. Environ.80, 185-201.

GAMERS (2017). Geospatial Analysis Mapping and Environmental Research Solutions. gamers.com.ng. (Accessed October 17, 2019).

Hansen, MC; Loveland, TR (2012). A review of large area monitoring of land cover change using Landsat data. Remote Sen.Environ.122, 66-74.

Ishaku, HT; Majid, MR (2010). X-Raying Rainfall Pattern and Variability in Northeastern Nigeria: Impacts on Access to Water Supply. J. of Water Res. Protection, 2, 952-959

Ju, J; Roy, DP (2008). The availability of cloud-free Landsat ETM+ data over the conterminous United States and globally. Remote Sen.Environ.112, 1196-1211.

Omo-Irabor OO; Oduyemi, K (2006). A hybrid image classification approach for the systematic analysis 
of land cover (lc) changes in the Niger Delta region: Proceedings of the $6^{\text {th }}$ Int' 1 conference on earth observation and geo-information sciences in support of Africa's development. Cairo, Egypt.

Rokonuzzaman, MD; Rahman, MM (2017). Effect of Cloud Coverage on Sunshine, Humidity, Rainfall and Temperature for Different Weather Stations in Bangladesh: A Panel Analysis. IOSR J. of Environ. Sci. Toxicology Food Tech.(IOSRJESTFT). 2(3) 2319-2399.

Twumasi, YA; Merem, EC (2006). GIS and Remote Sensing Applications in the Assessment of Change within a Coastal Environment in the Niger Delta Region of Nigeria. Int'l J. Environ. Res. Pub. Health. 3(1): 98-106

Uchegbulam, O; Ayolabi, EA; Adeoti, L (2017). Integration of Remote Sensing and Electrical Imaging in Assessing the Impact of Oil Exploitation in Parts of Western Niger Delta. Confluence J. of Environ. Studies. 11(2): 89-102

Uchegbulam, O; Ayolabi, EA (2013).Satellite Image Analysis using Remote Sensing Data in Parts of Western Niger Delta, Nigeria. J. Emerg. Trends in Engr. Appl. Sci. (JETEAS) 4(4):612-617
Urhobo Historical Society (2020) http://www.waado.org/ nigerdelta/Maps/Oilfields.html (Accessed 18.03.2020).

Wali, E; Phil-Eze, POI; Nwankwoala, HO; BoscoAbiahu, LC; Emelu, V (2019). Analysis of Land Use and Land Cover Changes in the Wetland Ecosystem of Port-Harcourt Metropolis, Nigeria. Engr. Mgt. Res. 8(2) EISSN 1927-7326

Wali, E; Nwanwoala, HO; Ocheje, JF; Chinedu, JO (2019). Oil Spll Incidents and Wetlands Loss in Niger Delta: Implication for Sustainable Development Goals. Int'l J. Environ. Pollute. Res. 7(1), 1-20

Yang, X; Lo, CP (2002).Using a time series of satellite imagery to detect land use and land cover changes in the Atlanta, Georgia metropolitan area. Int'l J. of Remote Sen.23, 1775-1798. 